\title{
QUEEN'S
UNIVERSITY
BELFAST
}

\section{Debating Darwin at the Cape}

Livingstone, D. (2016). Debating Darwin at the Cape. Journal of Historical Geography, 52, 1-15.

https://doi.org/10.1016/j.jhg.2015.12.002

\section{Published in:}

Journal of Historical Geography

\section{Document Version:}

Peer reviewed version

Queen's University Belfast - Research Portal:

Link to publication record in Queen's University Belfast Research Portal

\section{Publisher rights}

(c) Elsevier 2016 .

This is an open access article published under a Creative Commons Attribution-NonCommercial-NoDerivs License

(https://creativecommons.org/licenses/by-nc-nd/4.0/), which permits distribution and reproduction for non-commercial purposes, provided the author and source are cited.

\section{General rights}

Copyright for the publications made accessible via the Queen's University Belfast Research Portal is retained by the author(s) and / or other copyright owners and it is a condition of accessing these publications that users recognise and abide by the legal requirements associated with these rights.

\section{Take down policy}

The Research Portal is Queen's institutional repository that provides access to Queen's research output. Every effort has been made to ensure that content in the Research Portal does not infringe any person's rights, or applicable UK laws. If you discover content in the Research Portal that you believe breaches copyright or violates any law, please contact openaccess@qub.ac.uk. 


\section{Debating Darwin at the Cape}

On $31^{\text {st }}$ May 1836, the Royal Navy's surveying barque, HMS Beagle, dropped anchor at Simon's Bay near Cape Town. On deck was the young Charles Darwin who, nearly four and a half years earlier, had stepped aboard the vessel as a budding geologist and table companion to Captain Robert Fitzroy who had been assigned the task of charting the coastline of South America and determining meridian distances in the southern hemisphere. The Royal Observatory outside Cape Town was a crucial port of call, and with Sir John Herschel, Britain's highly distinguished astronomer, currently residing in Cape Colony on a four-year project to catalogue the stars, clusters and nebulae of the southern skies, the Beagle's crew found themselves in the Cape for eighteen days - a longer stay than anywhere else on the whole voyage save for the Galápagos Islands. For all that, Darwin was remarkably silent about the Cape. ${ }^{1}$ For the fact of the matter is that Darwin did not take to the colony much at all. In his diary entry for $4^{\text {th }}$ June he confessed "I saw so very little worth seeing, that I have scarcely anything to say". The landscape he found "bleak and desolate", its aspect "cheerless" and the Ruggensveld region devoid of interest. ${ }^{2}$ His private notes on Paarl Rock never saw the public light of day and his reflections on the Sea Point granite-slate contacts were reduced to the briefest of remarks in his 1844 Geological Observations on Volcanic Islands. ${ }^{3}$ But if Darwin more or less entirely ignored the Cape in his writings - though he did remain in touch with a number of correspondents there - the same cannot be said of the Cape's reaction to his theories. For during the late 1860s and 1870s, when controversy surrounding the theory of evolution by natural selection was bursting into full flame, the Cape Monthly Magazine in particular carried a spate of articles subjecting Darwinism to sustained scrutiny.

The Cape Monthly had come into being in 1857 under the editorship of Roderick Noble who taught at the South African College, and was designed to advance the virtues of intellectual enlightenment, social progress, and the spread of civilization in the Cape. ${ }^{4}$ As Saul Dubow remarks, the "Monthly combined the seriousness of purpose characteristic of the highbrow British quarterlies ... and lay at the center of an

\footnotetext{
1 Wilhelm S. Barnard, "Darwin at the Cape", South African Journal of Science 100 (2004): 243-48.

${ }^{2}$ See entries for June 1836, in Charles Darwin's Beagle Diary ed. Richard Darwin Keynes (Cambridge:

Cambridge University Press, 1988). See also Barnard, "Darwin at the Cape", p. 245.

3 On Darwin's account of the Sea Point contacts see Sharad Master, "Darwin as a Geologist in Africa Dispelling the Myths and Unravelling a Confused Knot", South African Journal of Science 108 No 9/10 (2012): $1-5$.

${ }^{4}$ See the discussion in Saul Dubow, A Commonwealth of Knowledge: Science, Sensibility, and White South Africa 1820-2000 (Oxford: Oxford University Press, 2006), chapter 2.
} 
interlocking network of associated colonial institutions and societies such as the South African Library, Museum, the Art Gallery and the University of the Cape of Good Hope". ${ }^{5}$ Aspiring to involve itself in the global scientific conversation, its editors kept their eyes "firmly fixed on developments in the imperial centres of London and Edinburgh". 6 Thus while much original work on the local geography and anthropology of the Cape itself graced the Monthly's pages, its tone was, by and large, that of a liberal intelligentsia seeking a place at the international scientific table during a time when the colony was absorbed with railway construction, diamond mining, and the establishment of 'Responsible Government' with the appointment of its own Prime Minister in 1872.

As elsewhere, the Darwinian debates in the Cape really only surfaced during the late 1860s and 1870s, and progressively intensified as the new decade wore on owing, in large measure, to the appearance of the Descent of Man in 1871 which directly applied the theory of evolution by natural selection to the human race, and to the furore surrounding John Tyndall's infamous presidential address to the 1874 meeting of the British Association for the Advancement of Science in Belfast. Taken in the round, exchanges over Darwin's proposals were conducted with notable civility, certainly compared with other venues, though worries over materialism were increasingly voiced in the aftermath of Tyndall's incursion. There were, too, novel mobilisations of Darwinism for purposes of immediate cultural relevance to the colony - especially in the fields of legislation and linguistics - which had significant racial resonances. Charting something of these engagements in the cultural space marked out by the English-speaking network that congregated around the Cape Monthly Magazine, the African Library and the like, is my ambition in what follows. ${ }^{7}$

This inquiry is intended to further contribute to the growing literature on the geographies of scientific knowledge in general, and the historical geography of Darwinism more particularly, by tracing in some detail the ways in which Darwin's theory was talked about and acted upon in the Cape during the decades around 1900. By examining the practices of science and the responses of the Cape's intellectual elite to the latest theoretical proposals, it is intended to make a contribution to understanding something of the nature of scientific culture in a colonial setting. At the same time, by inspecting the diverse range of spheres into which evolutionary thinking was drawn -

\footnotetext{
${ }^{5}$ Saul Dubow, "Earth History, Natural History, and Prehistory at the Cape, 1860-1785", Comparative Studies in Society and History 46 (2004): 107-133, on p. 109.

${ }^{6}$ Dubow, Commonwealth of Knowledge, p. 71.

${ }^{7}$ How Afrikaner culture engaged with Darwin's proposals in this period, so far as I am aware, remains to be explored.
} 
philology, natural history, anthropology, religion, philosophy, geology, law - it demonstrates just how wide-ranging the Darwinian debates were in the Colony's public square. What also emerges from this analysis is the complex geography of exchange between Europe and the Cape with the circulation of people, print and opinion across the imperial domain rendering local scientific cultures a compound product of both 'here' and 'there'.

\section{Early Encounters}

Initial reactions to Darwin at the Cape were articulated in a setting already favourably disposed to scientific inquiry. The Scottish-born physical scientist, Roderick Noble, Professor at the South African College, public lecturer and editor of the Cape Monthly, ${ }^{8}$ for example, had expressed his views on the science of geology in a lecture delivered to the Mechanics Institute in 1854. Noble was deeply religious - he had studied for the ministry in Edinburgh - and was well acquainted with the tradition of Scottish Common Sense philosophy, lecturing on such figures as Dugald Stewart and Thomas Reid. Such predilections favourably disposed him to the scientific enterprise and his lecture Geology: Its Relation to Scripture was sculpted in dialogue with his theological heritage. Here no trace of literalist scriptural geology surfaced. ${ }^{9}$ Instead, calling on the authority of such figures as Thomas Chalmers, John Pye Smith, Hugh Miller, and Edward Hitchcock, not to mention Cardinal Wiseman and Archbishop Whately, he argued that they had developed a variety of hermeneutic schemes - basically harmonising strategies - showing how a lengthy earth-history was entirely compatible with enlightened readings of the Genesis narrative. Geology's compatibility with popular religious sentiment was a different matter; but Noble assured his audience that "no such antagonism or irreconcilableness does in reality hold". ${ }^{10}$ Later in 1868 , in another public lecture, this time to the South African Public Library, an institution renowned for its rich manuscript resources, he insisted there was no inevitable conflict between Darwinian evolution and Divine

\footnotetext{
${ }^{8}$ See William Beinart, The Rise of Conservation in South Africa: Settlers, Livestock and the Environment 1770-1950 (Oxford: Oxford University Press, 2008); W.J. De Kock (ed.) Dictionary of South African Biography (Cape Town: Tafelberg, 1968-1981) Vol. II, p. 518-519.

${ }^{9}$ On scriptural geology see Ralph O’Connor, "Young-earth Creationists in Early Nineteenth Century Britain? Towards a Reassessment of 'Scriptural Geology”, History of Science 45 (2007): 357-403; Rodney L. Stiling, "Scriptural Geology in America", in David N. Livingstone, D.G. Hart and Mark A. Noll (eds), Evangelicals and Science in Historical Perspective (New York: Oxford University Press 1999), pp. 177-92; James R. Moore, "Geologists and Interpreters of Genesis in the Nineteenth Century", in David C. Lindberg and Ronald L. Numbers (eds), God and Nature: Historical Essays on the Encounter between Christianity and Science (Berkeley: University of California Press, 1986), pp. 322-50.

${ }^{10}$ Roderick Noble, Geology: Its Relations to Sacred Scripture. A Lecture Delivered to the Cape Town Mechanics' Institute in the Town Hall, on the 11 $1^{\text {th }}$ August, 1854 (Cape Town: Saul Solomon, 1854), p. 11.
} 
revelation. Certainly he entertained doubts about the universal efficacy of natural selection, but was convinced that it operated as a vera causa in the natural world. "So far as it goes, it is unquestionably true" he declared; "There is no doubt that great variations in type are produced in the manner described by Mr. Darwin". ${ }^{11}$ But its operations were constrained within definite limits. Noble was sure that it could not effect species transmutation nor that spontaneous generation had ever been directly observed. Darwin's use of pigeon breeding as the analogy par excellence for natural selection was a case in point. After all was said and done, the pigeons still remained pigeons, regardless of the stunning array of variants the breeders were able to produce. At the same time, Noble was no less certain that those who thought evolution was atheistic were very far mistaken. "I do not think that either ridicule or indignation is a just or reasonable ground on which to controvert it", he concluded. "There is nothing in the idea of development by such natural laws as Darwin speaks of which is irrational in itself or inconsistent with the most reverent acknowledgement of the Creator as evolving the scheme of the universe, thus naturally and continuously, instead of by successive acts of specific creation". ${ }^{12}$ The tone of Noble's interrogation was thus entirely in keeping with the South African Library's establishment aspirations and the hope that it would be to the Cape what the British Museum's library was to Great Britain.

Noble's temperate take on Darwin was also reflected in his dissemination of the verdict on the struggle for existence issued by another Scotsman and enthusiast for Common Sense philosophy, the geologist John Shaw of Colesberg. For in 1869 Noble published Shaw's treatment of the subject in a collection of essays he put together under the title The Cape and Its People. Shaw had set himself the task of determining the implications of nature's strife for natural theology and, understandably, Darwin's theory came directly within the radius of his concerns. Shaw was convinced it was high time that the traditional Paleyite settlement was refashioned so as to "vindicate the character of the Creator" in the face of "cruelty, pain, and death". ${ }^{13}$ A new economy of nature was required, one in which Darwin's iron law of survival held a prominent place, and which took seriously life's perpetual battlefield. For it was just simply a brute fact that "Everywhere there is a warfare, remorseless, uncompromising, impartial, in which the

\footnotetext{
${ }^{11}$ Roderick Noble, "Address", Proceedings at the Thirty-Ninth Anniversary Meeting of the Subscribers to the Public Library, Cape Town, Cape of Good Hope, Held on Saturday, the 23rd May, 1868 (Cape Town: Saul Solomon, 1868), pp. 8-35, on pp. 29-30.

12 Noble, “Address", p. 32.

${ }^{13}$ John Shaw, "The Struggle for Existence in Nature, and Its Relation to Speculations in Natural Theology", in Professor [Roderick] Noble (ed.), The Cape and Its People and Other Essays by South African Writers (Cape Town: J.C. Juta, 1869), pp. 63-78, on p. 63.
} 
weak go to the wall. In nature the race is to the swift and the battle to the strong; and all enter the lists". ${ }^{14}$ Whether it was to do with the fate of starlings in Western Scotland, locusts in South Africa, orchids in England, or Maoris in New Zealand, Universal Darwinism prevailed. But this state of pervasive extermination was not to be castigated as a malign thing, as too many natural theologians seemed to think. To Shaw it was a sublime revelation that illuminated the "balance of power in the opposing forces of Nature" by disclosing the intricate chains of life which bound all organisms together. ${ }^{15}$ For the result was ubiquitous improvement. And that was the clue to developing a natural theodicy which could justify annihilation of the individual as the price to be paid for enhancement of the species. "The struggle for existence", he affirmed, "cuts off every worthless form from Nature, and so keeps created life in perfection. It has been said that Nature of herself has nothing imperfect, maimed, and worthlessly weak. Every organism, however slightly impaired, must, inevitably, by this law be overtaken and eradicated. In fine, the struggle for life is a scavenger to clear away disease; it is a conservator, for it prevents the entrance of deterioration; it is a bountiful provider". ${ }^{16}$ How short-sighted then for theologians to dismiss this law as "physical evil". How could "that be called physical evil which carries with it everywhere physical good?" Such writers "in their ignorance and bigotry, have written a lie on the fair face of God's earth" ${ }^{17}$ In idioms reminiscent of Henry Drummond's later Natural Law in the Spiritual World, Shaw concluded:

In the far future, as in a dream, I see a vision, when Natural Theology, reared on a purely scientific basis, and built by the testimony of Nature's revelations, will raise its massive structure to meet the descending ladder of God's revealed truth. I can see a glimmering of this happy consummation in the dawning of a unity of plan in the natural and spiritual worlds - a law of suffering and struggle in both ... In the wonderful subordination of the one to the other of death and life, pain and pleasure, sorrow and joy, suffering and conquering, which follow in the wake of this remorseless law of warfare and competition, I can see an adumbration of man's spiritual experience". ${ }^{18}$

\footnotetext{
${ }^{14}$ Shaw, "The Struggle for Existence", p. 66.

${ }^{15}$ Shaw, "The Struggle for Existence", p. 72.

16 Shaw, "The Struggle for Existence", p. 74.

${ }^{17}$ Shaw, "The Struggle for Existence", p. 76.

${ }^{18}$ Shaw, "The Struggle for Existence", p. 77.
} 
Rather less enthusiastic was the judgment of Sir Henry Barkly, currently governor of the Cape having previously held similar positions in British Guiana, Jamaica, and Victoria. While in Australia, in his capacity as President of the Royal Society of Victoria, he had expressed misgivings about the subversive effects of the "grosser theory of progressive development" and worried over its social implications in an environment where turmoil was breaking out in the wake of the gold rushes. Barkly conceded that "the ingenious author of the new theory of the Origin of Species by natural selection" might well have provided a persuasive account of intra-species variation; but problems arose when the theory was "pushed to such extremes" as to derive "the most strongly marked 'natural orders' of plants and animals from a very few originals". ${ }^{19}$ At the Cape similar reservations surfaced. Thus in his May 1871 lecture to the Subscribers to the South African Library, he exempted the human race from the reign of evolution on account of "the total absence of transitional forms" but insisted that he was not opposed to its application to the rest of the animal kingdom: "I cannot but suppose that Evolution has played an important part in the formation of the various genera and species of plants and animals", he conceded. Nevertheless he was dismayed at the materialism that seemed to govern contemporary science, the positivism that prevailed in philosophy, and the creeping sense that "instead of God having made man" it was increasingly fashionable to suspect that it might be precisely the other way round. Still, while he espoused a hybrid account of zoological history - fusing creationist and evolutionary mechanisms - he held Darwin in high esteem: "I have the highest respect for Mr. Darwin. The moderation with which he states his views, and the candour with which he sets forth objections to them, are above all praise". ${ }^{20}$ Like Noble, moreover, Barkly insisted that even if human evolution by natural selection were to be confirmed beyond a shadow of doubt, the theological shockwaves could be easily absorbed.

More conspicuously supportive was the anonymous review of The Descent of Man that appeared in 1871 in the Cape Monthly Magazine whose author welcomed Darwin's latest offering adding that many readers of the "renowned Origin of Species" had registered surprise that Darwin had not taken up the subject of human evolution in his earlier

\footnotetext{
${ }^{19}$ Sir Henry Barkly, "Anniversary Address of the President for 1861", Transactions and Proceedings of the Royal Society of Victoria During the Years 1861 to 1864, 6 (1865): xix-xxxiv, on p. xxv. See the brief discussion in Barry W. Butcher, "Darwin Down Under: Science, Religion, and Evolution in Australia", in Ronald L. Numbers and John Stenhouse (eds), Disseminating Darwinism: The Role of Place, Race, Religion, and Gender (Cambridge: Cambridge University Press, 1999), pp. 39-59 on p. 44.

${ }^{20}$ Sir Henry Barkly, "Address", Proceedings at the Forty-Second Anniversary Meeting of the Subscribers to the South African Public Library, Cape Town, Cape of Good Hope, Held on Saturday, the 27th May, 1871 (Cape Town: Saul Solomon, 1871), pp. 9-26, on pp. 13, 12,11. Several extracts from the address are quoted in "Notes by the Editor", Cape Monthly Magazine 2 (June 1871): 381-384 on p. 383.
} 
volume. ${ }^{21}$ The writer was convinced that "the more complete our knowledge of organic structures becomes, only the stronger and more convincing grows the evidence that the wide interval formerly supposed to exist between the highest animal and those next to him in rank can no longer be insisted on, and must ultimately be recognized as imaginary. The differences that do exist are palpably differences of degree only, and not of kind". ${ }^{22}$ Initially the anonymous reviewer turned to Darwin's thinking on the role of sexual selection in racial differentiation, but soon came to the view that Darwinism's real challenge lay in the expansion of evolution's empire into the moral and mental realms. The article laid out Darwin's account with clarity and disinterest, though the author did pause to insert a lengthy excerpt from John Henry Newman insisting that it was "pregnant with warning to those who would hastily condemn views of the mental and moral status of animals such as Mr. Darwin so ably suggests". ${ }^{23}$ To be sure, the writer was in no doubt that the Descent of Man "will meet with severe (and in many quarters hostile) criticism", but remained convinced that "highly speculative though it is and as its author admits it to be", the Descent "is not a work to be treated lightly or contemptuously, as if it were but the crude notions of a mere fanciful theorist". "Whatever errors the progress of discovery may reveal in the elaborate superstructure of Evolution" the author concluded, “...it must be acknowledged that the foundations are securely based upon the broadest and firmest of the known facts of organic existence". ${ }^{24}$

Less convinced, it seems, was the anonymous contributor who used the death of the great Swiss-born naturalist Louis Agassiz, in December 1873, as an occasion to juxtapose Darwin's theory with the fixist views of the Harvard palaeontologist. Reprinting the memorial from the New York Times, along with a lengthy extract from Agassiz's Evolution and Permanence of Type just published in the Atlantic Monthly, this writer interpolated his own observation that because "the Darwinian theory" was "so often spoken of by sciolists and dogmatists as an established and demonstrated truth ... it will serve a good purpose to show that one of the foremost, if not the very first, naturalist of the age rejects it altogether as being anything more than a mere interesting speculation". ${ }^{25}$

In religious circles varying judgements on Darwin were also forthcoming. On the most oppositional front was the Archdeacon of George, Peter Parry Fogg, later VicarGeneral of St Helena, who penned an intemperate piece for the Cape Argus in October

\footnotetext{
21 “The Descent of Man”, Cape Monthly Magazine 2 (June 1871): 321-330, on p. 321.

22 "The Descent of Man", pp. 322-323.

23 "The Descent of Man", p. 325.

24 “The Descent of Man", pp. 329, 330.

25 "Agassiz and the Darwinian Theory", Cape Monthly Magazine 7 (1874): 250-253, on p. 251.
} 
1872 claiming that Darwin's theory was “absurd”, because it was self-contradictory; "baseless", because of its evidential paucity; and "monstrous", because it subverted religion. As part of his argument against human evolution he urged that among "the races of Africa" were some of the "lowest specimens of humanity and almost side by side with them is found man's pretended ancestor, the gorilla" and that black degradation was evidence enough to refute the idea of progressive evolution. ${ }^{26}$ By contrast, while he was not convinced that the theory as yet enjoyed undisputed empirical corroboration, the Reverend (later Sir) Thomas E. Fuller, Baptist pastor, journalist and liberal politician, as well as confidant and biographer of Cecil Rhodes, told the readers of the Cape Argus - of which he was editor - in April 1871 that Christian believers had nothing to fear from human evolution were it shown to be true. "It would not affect those human instincts which constitute the root of religious, moral and refined sentiment", he announced, nor indeed "belief in the historic development of religious faith".

These rather high-altitude dealings with Darwinism ran the gamut of opinion from occasional repudiation and reluctant tolerance to partial endorsement and enthusiastic advocacy. But the prevailing sense of these early appraisals is of a liberal intelligentsia calmly interacting with a novel theory with all due deference. Even if its more farreaching speculations about human ancestry came to be confirmed, the Cape Monthly's contributors gave every impression that the settled cosmos of Cape Colony could fairly painlessly accommodate itself to the new evolutionary framework.

\section{Birds, Butterflies and Bushmen}

Engagements with Darwin's proposals, however, were not simply philosophical or theoretical. The scientific significance of his explanations for empirical inquiries of various kinds also surfaced. Hugh Exton, geologist, scientific traveller, ornithologist and medical practitioner, ${ }^{27}$ for example, turned to both Alfred Russel Wallace and Darwin in 1871 when examining the question of whether the nest-building capability of birds was a natural instinct or an acquired adaptive trait which implied "the exercise of mental powers" involving observation, memory and imitation. ${ }^{28}$ While, like Darwin, Exton wanted to retain instinct as an explanatory force, he readily conceded that birds did indeed possess the mental capacity to perform some complex acts. A few years later, in a

\footnotetext{
${ }^{26}$ Both of these are discussed in Robert Vicat Turrell, "A Cape Periodical: The Cape Monthly Magazine (1870-1875)", B.A. Dissertation, University of Cape Town, 1974). Quotations appear on pp. 47, 48. ${ }_{27}$ Dictionary of South African Biography, Vol. II, pp. 282-283.

${ }^{28}$ H. Exton, “The Philosophy Of Bird's Nests In Relation To Instinct”, Cape Monthly Magazine (June 1871): 342-354 on p. 343.
} 
very favourable review of the new edition of E.L. Layard's Birds of South Africa, he noted how the volume's system of classification had followed the schema developed in Wallace's Contributions to the Theory of Natural Selection which acknowledged that "species have become modified in accordance with changes in their external conditions" and took seriously the evolutionary "Order in which the several species came into existence". ${ }^{29} \mathrm{He}$ cited Darwin too on the adaptive role that mimicry played in the colouration of cuckoo eggs.

In comparable vein J.C. Seaman, another medical practitioner, published an essay designed to test the hypothesis that colour variation in butterflies could be explained by the influence of climatic conditions on the chrysalis stage of Lepidoptera development. Temperature directly determined the duration of this phase of the insect's life-cycle, and thus the time of the emergence of the pupa from the larva. Seaman believed that he had field evidence to support the view that a butterfly's markings reflected the length of time it had been in the chrysalis state, and he was inclined to think that the early onset of pupation was thus a "primary cause of variation" since such insects bore the marks of premature evolution. He made it clear, however, that this process did not produce new species and called on "Mr Darwin's researches on atavism or reversion to type" to confirm that "modifications produced by certain causes disappear with the cessation of that action". 30

The most far-reaching recruitment of Darwinian idioms for research purposes, however, was in the field of African philology by Wilhelm H. I. Bleek whose celebrated investigations into the development of language were conducted within the framework of the evolution of species. What leant particular cultural significance to Bleek's project was the racial prism though which his work on the colony's indigenous language systems was refracted. While perhaps rather less frequently paraded in the Cape than among the cognoscenti in other places where racial politics dominated the horizon, ${ }^{31}$ the Darwinian implications for race relations certainly surfaced. Bleek, the son of a distinguished theologian, had come out to Cape Colony in the mid 1850s at the urging of Bishop John

\footnotetext{
${ }^{29}$ H. Exton, "The Birds of South Africa”, Cape Monthly Magazine 13 (December 1876): 342-349 on p. 342.

${ }^{30}$ J. C. Seaman, "Variation in Butterflies", Cape Monthly Magazine (August 1871): 77-80, on p. 80.

${ }^{31}$ I have in mind New Zealand and the American South. On these see Lester D. Stephens, Science, Race, and Religion in the American South: John Bachman and the Charleston Circle of Naturalists, 1815-1895 (Chapel Hill: University of North Carolina Press, 2000); John Stenhouse, “The Darwinian Enlightenment and New Zealand Politics", in Roy MacLeod and Philip F. Rehbock (eds), Darwin's Laboratory: Evolutionary Theory and Natural History in the Pacific (Honolulu: University of Hawaici Press, 1994), pp. 395-425, and John Stenhouse, "Darwinism in New Zealand, 1859-1900", in Ronald L. Numbers and John Stenhouse (eds), Disseminating Darwinism: The Role of Place, Race, Religion, and Gender (New York: Cambridge University Press, 1999, pp. 61-89. See also my "Science, Text and Space: Thoughts on the Geography of Reading", Transactions of the Institute of British Geographers 30 (2005): 391-401.
} 
W. Colenso to assist in the compilation of a Zulu grammar, and he acquired for himself a major reputation as a comparative philologist. He quickly became a dominating figure in the intellectual life of the Cape where he advocated German Higher Criticism and defended the heretical Colenso, who entertained unorthodox views on the compatibility of polygamy with Christianity and urged that scientifically dubious statements in the Bible should be dismissed as mythological. ${ }^{32} \mathrm{He}$ was also a regular contributor to the Monthly from its inception until his death in $1875 .{ }^{33}$

Bleek's analysis of African languages fitted very comfortably into a social evolutionary developmental schema. As he explained to the readers of the Cape Monthly in 1873, the languages spoken within the Colony were of major scientific importance because they exemplified very early forms of the three families that he believed encompassed the vast bulk of human tongues. Kafir was "the key" to elucidating prefix-pronominal languages; Hottentot exhibited "the most primitive" type of sex-denoting languages; and Bushman, which had no sense of gendered nouns, was critical to solving the problem of the genderless or Turanian languages. To Bleek, the Bushmen were of special importance, for he was sure that with them he was in direct contact with language users who occupied "the lowest position with regard to civilization" at a particularly early stage of mental development. ${ }^{34}$

Bleek had long maintained that the study of philology was fundamentally a moral science in the sense that its whole animus was to "elucidate the history and the whole course of the development of human-kind, and to give an insight into the character of man, and the varying nature of the human mind". With that conviction firmly in place from shortly after his arrival in southern Africa, he was persuaded that the Cape provided an ideal laboratory for solving the problems of the evolution of human language systems. The very primitive stage of development of the indigenous peoples, he had announced in the pages of the Monthly in 1858, rendered "them peculiarly fit to serve as safe bases for ample comparative ethnological and philological researches ... inasmuch as the higher stages of the development of our race can only be properly understood by tracing them from their original forms, which cannot have been very dissimilar to the primary types, as they are, in great measure preserved in the customs,

\footnotetext{
${ }^{32}$ R. J. Thornton, “'This Dying Out Race': W.H.I. Bleek's Approach to the Languages of Southern Africa", Social Dynamics: A Journal of African Studies, 9, 2 (1983), 1-10.

${ }^{33}$ His early contributions included W. H. I. Bleek, "Researches into the Relations Between the Hottentots and Kafirs", Cape Monthly Magazine (April, 1857): 199-208; W. H. I. Bleek, "Researches into the Relations between the Hottentot and Kafir Races", Cape Monthly Magazine (May, 1857): 289-96.

${ }^{34}$ W.H.I. Bleek, "Scientific Reasons for the Study of the Bushman Language", Cape Monthly Magazine 7 (September, 1873): 149-153, on p. 150.
} 
habits, languages, and ideas of the Kafirs on the one side, and the Hottentots on the other" ${ }^{35}$ Indeed in many ways it was the sense that in such peoples the human species was in touch with its own early history which underlay Bleek's preservationist efforts to gather together Bushman myths, legends, customs, songs, and the like ${ }^{36}$ - a project on which he reported in the Montbly. ${ }^{37}$ To Bleek, as Patrick Harries observes, "tales and songs could be put together and analyzed in much the same way as the sounds of dying languages that through careful comparison could take philologists back to the beginnings of time". ${ }^{38}$

Given these predilections, it is not surprising that when his work On the Origin of Language was eventually published in the late 1860s, first in German and then in English translation, he recruited his cousin, none other than Ernst Haeckel, Darwin's chief German apologist, to write a preface to the treatise. For his part, Bleek collected corals and other marine specimens for Haeckel which contributed significantly to his cousin's innovative research on marine invertebrates. ${ }^{39}$ While the bulk of the work had actually been completed in 1853, Bleek was more than happy to have its thorough compatibility with the latest thinking on evolution prominently advertised. ${ }^{40}$ After all, not only did he regularly correspond with Darwin himself during his years in the Cape, but the full title of the work ran On the Origin of Language as a First Chapter in a History of the Development of Humanity. Haeckel readily complied with Bleek's request and thoroughly Darwinised the narrative by going out of his way to insist that it would "derive advantage" from the appearance of Darwin's great work. ${ }^{41}$ Nor did he miss the work's serviceability in furthering the science of human evolution ... and its racial implications. "42 "Hottentots, the Bushmen, the Kaffirs and others ... have remained, down to the present day, at the

\footnotetext{
35 W.H. I. Bleek, “South African Philology”, Cape Monthly Magazine (January, 1858): 21-27, on pp. 23-24.

${ }^{36}$ On this preservationist project see Pippa Skotnes, Claim to the Country: The Archive of Wilhelm Bleek and Lucy Lloyd (Athens, OH: Ohio University Press, 2007).

${ }^{37}$ See for example, W.H.I. Bleek, "African Folk-lore”, Cape Monthly Magazine (December 1871): 334-343; "Bushman Researches", Cape Monthly Magazine 11 (August 1875): 104-115; “Bushman Researches. Part II”, Cape Monthly Magazine 11 (September 1875): 150-155. Along with the Bushmen, Bleek identified the "natives of Australia ... and some of the Indian nations living to the West of the Rocky Mountains" as "probably the lowest types of humanity, as regards civilization and deficiency of political organization." W.H.I. Bleek, "On Inquiries into Australian Aboriginal Folklore”, Cape Monthly Magazine 9 (September, 1874): 129-136.

${ }^{38}$ Harries, Butterflies and Barbarians, p. 47.

39 Thorton, "This Dying-Out Race" ".

${ }^{40}$ Wilhelm Heinrich Immanuel Bleek, Über den Ursprung der Sprache (Weimar: Hermann Boehlau, 1868); W.H.J. Bleek, On the Origin of Language. Edited with a Preface by Dr. Ernst Haeckel. Translated by Thomas Davidson (New York: L.W. Schmidt, 1869).

${ }^{41}$ Bleek, On the Origin of Language, p. vi.

42 The influence of Bleek on Haeckel is discussed in Mario A. di Gregorio, "Reflections of a Nonpolitical Naturalist: Ernst Haeckel, Wilhelm Bleek, Friedrich Müller and the Meaning of Language" Journal of the History of Biology 35 (2002): 79-109.
} 
lowest stage of human development, and made the smallest advance beyond the ape" Haeckel observed. "This is true not only in respect of their entire physical and moral characteristic, but also in respect of their language". In fact he felt it appropriate to remark on Bleek's intimate familiarity with "those lower races of men, who in every respect remind us of our animal ancestors, and who, to the unprejudiced comparative student of nature, seem to manifest a closer connection with the gorilla and the chimpanzee of that region than with a Kant or a Goethe". ${ }^{43}$ While perhaps less harsh in his racial judgments, Bleek fundamentally concurred. ${ }^{44}$ After all he located the speech of the Bushmen in the liminal zone between the simian and the human. Bushman was not itself the Ursprache, but was the closest living language to it. And so, when reflecting on "how far a system of [clicking] sounds like that of the Bushmen shows points of coincidence with sounds produced by the apes resembling man," he inserted a lengthy extract on ape language from Haeckel himself who in turn referred to Carl Vogt's ideas on human descent from simian ancestors. ${ }^{45}$ That was where Bleek's method led him: "we cannot arrive at a knowledge of the rise of humanity, the ascent of human nature from animal existence save by a comparison of the lowest conditions of humanity with those of the highest formations in the animal world". ${ }^{46}$

While Haeckel's name later caused consternation in the Cape community, as we shall presently see, Bleek's association with him does not seem to have prompted such disquiet. Several factors may have contributed. For a start, Bleek was far less sanguine about race classification than Haeckel on account of population blending; nor did he share his cousin's callous disdain for the Cape's peoples; and he remained less extreme on race hierarchy in part because of his strong convictions about humanity as a "single gigantic organism" cemented together by speech. ${ }^{47}$ Besides, his firm commitment to the monophyletic origin of language, in marked contrast to Haeckel's provocative denial, supported a monogenist conception of the human species and thus also buttressed the unity of humankind - a conviction that chimed with biblical confessionalism and colonial patronage alike. In a letter to his cousin in October 1874, for example, he insisted that "the more I study the lowest languages, the more I become convinced that probably all presently spoken languages have grown out of a formation which has taken place a long time ago", and went on to chide Haeckel for resorting to Max Müller as an "authority"

\footnotetext{
43 Bleek, On the Origin of Language, p. iv.

44 Bleek's racial thinking is the subject of Andrew Bank, "Evolution and Racial Theory: The Hidden Side of Wilhelm Bleek", South African Historical Journal 43 (2000): 163-178.

${ }^{45}$ Bleek, On the Origin of Language, p. 53.

${ }^{46}$ Bleek, On the Origin of Language, p. 45.

${ }^{47}$ Bleek, On the Origin of Language, p. xiii.
} 
supporting polyphylecticism with the barbed quip: "It is very clear that he does not understand the languages which he writes about". ${ }^{48}$ In addition, Bleek sustained lengthy correspondence with missionaries throughout the length and breadth of South Africa.

Moreover his outlook could be thought to fit rather well with the sentiment that 'lower races' could be improved through colonial tutelage and paternalistic governance. ${ }^{49}$

Bleek's standing therefore remained high. It was called upon by the missionarylinguist F.V. Kolbe, for example, who hoped that at a time when "the question of the Descent of Man is again engaging a good deal of public attention" there would be comparable interest in the origin of language. Kolbe was certain that even though the language-making capacity was the gift of divine reason, it was mistaken to think that "the first man was miraculously endowed with a copious philosophical language". ${ }^{50}$ The educationalist Langham Dale, who as we shall see remained hostile to Haeckel's evolutionism, was pleased to note that the "Professor pays a graceful tribute to the labours ... of our own friend Dr. Wilhelm Bleek" and hoped that "a worthy successor can be found to carry on and complete his studies of the South African languages". ${ }^{51}$ And the obituary notice of Bleek's death that appeared in the September 1875 issue of the Monthly remarked that the loss of this "kindly and warm-hearted ... helpful and trustworthy" scholar "was universally felt and emphatically acknowledged". The writer, moreover, did not miss the opportunity to portray Bleek as a humble servant of virtuous science by depicting a scene - in a single expansive sentence - which no less served to reinscribe the power-relations that governed colonial life:

Most interesting and suggestive was it to see the earnest, big-browed German, a

\footnotetext{
${ }^{48}$ Quoted in Thornton, “"This Dying out Race””, pp. 6, 7.

49 On political discourses in the Cape see Alan Lester, Imperial Networks: Creating Identities in NineteenthCentury South Africa and Britain (New York: Routledge, 2001). Elsewhere in southern Africa, evolutionary ideas were applied to anthropological questions with varying emphases. The Grahamstown naturalist Mary Barber, who corresponded with Darwin on plant pollination, used natural selection to justify a settler ideology and to interpret European dominance as a result of natural biological hierarchy. See S.D. Johnson, "Darwin's Legacy in South African Evolutionary Biology," South African Journal of Science 105 (2009): 403- 409; Alan Cohen, "Mary Elizabeth Barber: South Africa’s First Lady Natural Historian," Archives of Natural History 27 (2000): 187-208; Robert Shanafelt, "How Charles Darwin Got Emotional Expression Out of South Africa (and the People Who Helped Him)," Comparative Studies in Society and History 45 (2003): 815-842. Later the distinguished missionary-anthropologist, Henri-Alexandre Junod, found in Darwinism the grounds for a monogenist outlook that firmly kept Africans within the sweep of the human family while retaining ideas about Africans as juveniles who could only achieve adulthood through careful guidance. See Patrick Harries, Butterflies and Barbarians: Swiss Missionaries and Systems of Knowledge in South-East Africa (Oxford: James Curry, 2007).

${ }^{50}$ F.W. Kolbe, "The Origin of Language", Cape Monthly Magazine 3 (August 1871): 93-97 on pp. 93, 97. He was the author of "On the Bearing of the Study of the Bántu Languages of South Africa on the Aryan Family of Languages", Journal of the Royal Asiatic Society of Great Britain and Ireland 17 (1885): 38-58 as well as several volumes on Bantu.

51 [Langham Dale], “Anthropology”, Cape Monthly Magazine 12 (February, 1876): 118-123, on p. 123.
} 
typical example of the cultured intellect of his nation, with painstaking exactness and marvelous patience, repeating, analyzing, noting down every sound and syllable uttered by the semi-savage at his side, who - with his pigmy stature, prognathous dusky face, narrow forehead, sunken restless eyes, and harsh clicking ejaculations might well have passed for demon-imp of mediaeval story, compelled by the magic art of the alchemist-philosopher to reveal his jealously-hoarded secrets. ${ }^{52}$

By the early 1870s then, it is clear that Darwin's theories were being fairly widely discussed amongst the literati in Cape Town. Some resorted to Darwin as a scientific authority on empirical questions - such as mimicry, reversion to type and animal instinct - or found in Darwinism resources to grapple with subjects like the emergence of language. Outright rejection of the theory was relatively rare and even those who remained unconvinced by and large held Darwin himself in high regard. Selective endorsement of his proposals was much more typical than wholesale condemnation and efforts were even made to construct a kind of Darwinized natural theology that had the law of struggle located at its core. During the mid 1870s a step-change in the intensity with which Darwin's proposals were engaged is markedly registered in the pages of the Cape Monthly. Two statements that appeared in the magazine during 1874 stimulated a good deal of comment and reflection. The first of these was an address by Langham Dale, superintendent-general of education in the Cape Colony, and Vice-Chancellor of the University of the Cape of Good Hope.

\section{The Dale Debate}

In June that year, new vigour was injected into the debate courtesy of the speech Dale delivered at the annual meeting of the South African Public Library. An Oxford trained Mathematician Dale had secured his appointment as professor of English and Classics at Cape Town's South African College in 1848, having been recommended by none other than Sir John Herschel who had spent four years in the Cape during the early $1830 \mathrm{~s} .{ }^{53} \mathrm{He}$ enjoyed a long and distinguished career as an educationalist as well as acquiring a significant reputation as a pioneer of South African archaeology and private collector of Bantu artefacts..$^{54}$ Like other local champions of education he was profoundly committed to the value of instilling good reading habits among the working classes as a means of

\footnotetext{
52 R.T., "Wilhelm H.I. Bleek”, Cape Monthly Magazine 11 (September 1875): 167-169.

${ }^{53}$ Rob Siebörger, "Dale, Sir Langham (1826-1898)", Oxford Dictionary of National Biography, Oxford University Press, May 2006 [http://www.oxforddnb.com/view/article/61105, accessed 17 Nov 2015]. ${ }^{54}$ J.I.J.v.R., "Dale, Sir Langham”, Dictionary of South African Biography, Vol. I, pp. 201-204.
} 
promoting enlightenment virtues and was critical of what he regarded as Boer lethargy and resistance to the values of civilised culture and enlightened commerce. ${ }^{55}$ Because he remained convinced that education was the highroad to peace and civilization, throughout his time as superintendent-general of education he insisted that African schools should operate with similar curricular requirements as others and that government-maintained schools should be open to all children "without distinction of creed, class or colour." ${ }^{\prime 56}$ Later he was elected Vice-Chancellor of the new University of the Cape of Good Hope.

Dale took as the subject of his 1874 South African Library lecture "Anthropology A Review of Modern Theories". ${ }^{57}$ While the tenor of his assessment was restrained, his discomfort with a number of key components in the Darwinian edifice was plain for all to see. Written in a rather convoluted style, Dale rejected as untenable the idea of the stadial development of society through stone, bronze and iron ages; he worried over natural selection's capacity to produce the first truly human pair; he could not see how a natural process could deliver an immortal soul, nor - following Alfred Russel Wallace the ways in which "civilized man arrests those influences of nature which acted freely upon him in a low savage condition". Still, while favourably citing Agassiz's critique, he did nonetheless allow for the operation of natural selection as an agent of organic change though insisted that it failed to explain the origin of "the source of vital power" itself. More than half of his article, however, was given over to the question of the evolution of language. To Dale, there were "countless difficulties" facing any developmental account assuming that "interjectional utterances prompted by ... sensations" could be the "germ of articulate speech". ${ }^{58}$ This led him to announce that the "original unity of language" remained unproven and to look favourably on Max Müller's conviction that researchers could no longer aspire to trace all language to a common root. ${ }^{59}$ Such a theory, anyway, was much too premature and required a lot of empirical work in places like South Africa itself where some linguistic groups retained mechanical sounds which were supposed to be lingering "traces of the primal language". It was the same for comparative religious

\footnotetext{
${ }^{55}$ Dubow, Commonwealth of Knowledge, pp. 51, 114.

${ }^{56}$ Siebörger, "Dale, Sir Langham".

57 This was the title he chose for the piece when it appeared in the Cape Monthly. It was originally simply entitled "Address" when published in Proceedings at the Forty-Fifth Anniversary Meeting of the Subscribers to the South African Public Library (Cape Town: Saul Solomon, 1874).

${ }^{58}$ Langham Dale, “Anthropology - A Review of Modern Theories”, Cape Monthly Magazine 8 (June 1874): 350-362 on pp. 355, 353, 356.

${ }^{59}$ Dale, “Anthropology”, p. 357. On Müller see Stephen G. Alter, Darwinism and the Linguistic Image: Language, Race, and Natural Theology in the Nineteenth Century (Baltimore: Johns Hopkins University Press, 1999), p. 40.
} 
belief systems; as a subject of scholarly inquiry it was too poorly developed to provide support for speculations about including a "faculty of faith" among humanity's "mental attributes". ${ }^{60}$

Dale's intervention provoked a number of responses in the weeks that followed, but whatever stance they adopted, their tone was moderate and considered. In July, an anonymous author contributed an article on the question of the origin of language contesting Dale's anti-evolutionary declarations. The writer made it clear that the proposal that "language is a direct gift from Heaven is as consistent with the theory of physical evolution as with that of specific creation", but nonetheless argued that Dale's account of linguistic evolution was faulty. ${ }^{61}$ The idea that human speech could have developed by means of natural selection, or some related evolutionary mechanism, from the imitative articulations of pre-human hominids was entirely plausible to the author. By accumulative inflections, gestures, and modulations, a rudimentary language could easily come into being with increasingly abstract ideas finding limited expression. Such a hypothetical history, readers were told, was as compatible with orthodox Darwinism as with the theologised version of human evolution advanced by the English zoologist and Catholic polemicist St George Mivart. Whichever, the writer was certain that the truth or falsity of the proposal that evolution could enlighten the processes of linguistic acquisition should be adjudicated at the bar of science and not judged by theological preference. Dale was simply "injudicious" in the stance that he had adopted. For after all, if Darwin's theory turned out to be true, it "would leave the doctrine of the immortality of the soul, the Divine government of the world, and the doctrines of religion generally, as untouched as the old astronomical and geological discoveries of the motion and antiquity of the world". ${ }^{62}$

Another anonymous interlocutor fastened on Dale's use of Agassiz to sustain his scepticism over a Darwinian understanding of variation. The author prosecuted the differences between artificial and natural selection to combat Dale's contention that "extreme variations degenerate or become sterile". His line of argument ran along the following lines. Radical variations were usually the product of human intervention - as in the case of pigeon breeding - and these peculiar breeds could not be maintained without the constant oversight and intervening care of the human breeder. On the face of it, this seemed a "fatal objection" to Darwinian evolution. But that judgment was altogether too

\footnotetext{
${ }^{60}$ Dale, “Anthropology”, pp. 357, 359.

61 "On the Origin of Language", Cape Monthly Magazine 9 (July 1874): 15-19 on p. 15.

62 "On the Origin of Language", pp. 18, 19.
} 
hasty. It was just mistaken to infer the sterility of certain variations in nature from such artificial cases. Why? "Nature selects not for one quality", the author announced, "but for the whole assemblage of qualities which go to the continuance of the species.

Fertility, constitutional strength, ability to procure food, power to endure the vicissitudes of the climate, - every point, in fact, is considered in natural selection". Besides, nature worked "more patiently" than human breeders; it was "never in a hurry". In consequence what "at first sight appears to be a serious objection to theory of evolution turns out on consideration to be not only no objection at all, but even to explain an unanticipated difficulty", ${ }^{63}$

By far the most detailed interrogation of Dale's Library Address came from the pen of the Queenstown physician and later politician, Sir William Bisset Berry, an Aberdeeneducated surgeon who was appointed speaker of the House of Assembly after the general election of $1898 .{ }^{64}$ Berry had reportedly been involved in an earlier scuffle over Darwinism during the mid-1860s shortly after his arrival in Queenstown, but whatever happened there it did nothing to change his enthusiastically pro-Darwin stance nor to scupper his chances of election as first mayor of the town. The 1874 August and September issues of the Monthly ran a lengthy two-part assessment of Dale's account of evolution (it was much longer than Dale's original statement) in which Berry scrutinised and contested in painstaking detail each and every claim that Dale had announced in his Library Address. ${ }^{65}$ His rebuttal showed every evidence of familiarity with the work of leading scientific figures - among them Agassiz, von Baer, Owen, Döllinger, Oken, Mivart, Bastian, Maine, Lubbock and Tylor. To Berry evolution could comprehensively account for everything from species transformation and the emergence of mind to the development of sociality and the family, as well as moral sentiments and human language.

From the outset, Berry made it clear that he harboured no aversion to hypotheses and speculation - such as Agassiz affected to possess - and that the time at any rate had come "to warrant an attempt at some comprehensive generalization". In a marked departure from standard inductive procedure, Berry insisted that the absence of direct empirical observation provided no grounds for dismissing an imaginative and coherent scientific theory. Dale's resort to Agassiz thus troubled Berry a good deal and he

63 "Selection - Artificial and Natural", Cape Monthly Magazine 9 (November 1874): 276-277.

${ }^{64}$ Dictionary of South African Biography, Vol. II, pp. 55-56; see also J.K. De Kock, "Doctors in Parliament", South Africa Medical Journal (11 April 1964): 237-241.

${ }_{65}^{6}$ W. B. B[erry], "Dr. Dale on Evolution of Life", Cape Monthly Magazine 9 (August 1874): 95-106; 9 (September 1874): 151-158. 
cautioned him, with an aside that bordered on the acerbic, that the great Swiss natural historian's mordant anti-Darwinism stemmed from dread of "the pain of a new idea". ${ }^{66}$ On the religious questions that had occupied Dale, Berry remarked that Mivart had perfectly well shown how evolution was compatible with Catholic theology, for "in an age in which the Romish hierarchy is as jealous of belief as ever" it was notable that Mivart's The Genesis of Species had not found itself catapulted onto the Vatican's index of prohibited books. Dale's anxieties over the fate of the immorality of the soul if evolutionary theory were to gain a foothold, were thus misplaced. After all Bishop Butler's writings had long shown that there was "nothing repugnant to the articles of the Church of England" in the idea of "the natural immortality of brutes". ${ }^{67}$ As for humanity's simian ancestry, Berry contested Wallace's exemption of the human mind and brain from the operations of natural selection, and, relying heavily on John Fiske, made much of the fact that the difference in brain size between gorilla and 'Hindu' skulls was much smaller than that between Hindus and modern Englishmen. That netted humans and primates together in an entirely compelling way. Most of all Berry confessed himself “astonished" by Dale's declarations on human moral distinctiveness and, following John Locke, announced the demise of "the doctrine of an innate moral sense". With that presumption disappearing into the abyss, Berry concluded, "the last stumbling-block of the anti-evolutionist" was whisked away. ${ }^{68}$

A few weeks later, in the October issue, Dale replied to his critics. His tone was firm, but conciliatory, and while it is clear that he misconstrued some of the comments that his detractors had made, he insisted that some agnosticism on the explanatory value of evolution by natural selection did not mean that he intended to advance "an argument subversive of the truth of the theory, but only as a reason why the mind should be kept in a state of receptivity for further evidence". ${ }^{69}$ Here he briefly reiterated his feelings about the immutability of the human species, the absence of transitional forms in the fossil record, and his own sense that "a vital energy" pervaded the material world. Nevertheless he chose to end his commentary with the words of John Tyndall: "I do not think that the evolution hypothesis is to be flouted away contemptuously. I do not think it is to be denounced as wicked. It is to be brought before the bar of disciplined reason, and there justified or condemned. Let us hearken to those who wisely support it, and to

\footnotetext{
${ }^{66}$ B [erry], "Dr. Dale", pp. 97, 99.

${ }^{67}$ B [erry], "Dr. Dale", pp. 104-105, 106.

${ }^{68}$ B [erry], "Dr. Dale”, pp. 157, 158.

${ }^{69}$ [Langham Dale], “The Library Address”, Cape Monthly Magazine 9 (October, 1874): pp. 219-222, on p. 220.
} 
those who wisely oppose it; and let us tolerate those, and they are many, who foolishly try to do either of these things. The only thing out of place is dogmatism on either side". ${ }^{70}$

That same October issue carried another assessment of Darwin - this time a theological evaluation - under the initials W.G. The author's first sentence gave every impressive of radical dismissal. "The theory of evolution, as at present advocated by many scientific men, is at once repugnant to reason and opposed to the teachings of Revelation". Despite this cavalier denunciation - he had the likes of the anonymous author of Vestiges of the Natural History of Creation in his cross-hairs - the piece was actually characterised by a studied moderatism. For the author's tactic was to steer a middle course between "a certain class of men who have run wild in their pursuit and development of the theory" of evolution and champions of a literalist special creationism. His rejection of both camps was decisive. The former incorporated those like Darwin himself whom he accused of advocating spontaneous generation, Huxley who sought to narrow the gap between ape and human brains, and Lyell who had recently delivered "to our excited imagination the earth peopled with a race of naked little savages long prior to Bible Adam". ${ }^{71}$ The image of primitive savagery they had collectively conjured up was "diametrically opposed to the teachings of Scripture, and dangerous in its tendencies", and ran roughshod over the "doctrine of man's fall from a higher state of pristine innocence". ${ }^{72}$ At the same time, the theory of special creation was beset by numerous difficulties. The idea of the immediate creation of the first human from the dust of the earth seemed "altogether unnatural and contra-indicated by the whole method" of divine working in the world. It was, frankly, "altogether unsatisfactory to a reasoning and philosophic mind". W.G.'s own solution was, in essence, the proposal that Mivart had recently put forward in his 1871 Genesis of Species. Namely, by conceiving of the human species as "the possessor of two natures, a physical and a psychical". On the physical side, the writer went on, "man ... may be legitimately descended from an inferior race, while in virtue of his psychical [nature] he is a special act of Divine creation". That provided a middle way: "To maintain that in his body man is an evolution, and in his spirit he is a special creation at once removes the objections to

\footnotetext{
70 [Dale], "Library Address", p. 222.

71 W.G., "The Darwinian Theory (From a Theological Point of View)", Cape Monthly Magazine 9 (October 1874): 234-241, on p. 234. Turrell speculated that the author was probably the Rev W. Guard. See Turrell, “A Cape Periodical”, p. 53.

72 W.G., “The Darwinian Theory”, p. 236.
} 
the theory of evolution, and dissipates the philosophical objection to the special creation theory". ${ }^{73}$

Dale's Library Address injected fresh urgency into the evolutionary debates at the Cape, stimulating a range of responses to his queries which mostly sought to find ways of absolving Darwin of the changes Dale levelled at his theory. In mounting their defence, several interlocutors resorted to Mivart's dualist strategy of explaining human physical development in evolutionary terms while retaining divine intervention for the creation of the psyche. What is equally noticeable is that in these exchanges concerns over the question of materialism are conspicuous by their absence. That was to change in the very near future.

\section{The Belfast Connection}

Discussion of Darwinian matters further intensified the following month - November when a second provocative statement made its appearance in the Monthly. This was a reprint of copious extracts from John Tyndall's infamous Belfast address. That was a gunshot that echoed round the world. Back in August, Tyndall, President of the British Association for the Advancement of Science, had delivered his controversial presidential address in Ulster's metropolis. Here he threw down the gauntlet to the religious establishment by insisting that theology had no business meddling in scientific matters and adjudicating on origin theories. All "religious theories, schemes and systems which embrace notions of cosmogony" he proclaimed, “... must ... submit to the control of science, and relinquish all thought of controlling it. Acting otherwise proved disastrous in the past, and it is simply fatuous to-day". Along the way he expressed his enthusiasm for far surer guides - Democritus, Lucretius, Darwin, Spencer and the like - and took the trouble to pour scorn on the comfort theologians had derived from Newton's passion for divine revelation by insisting that brilliance in one sphere of inquiry was no guarantee of merit in another. Championing his own brands of atomism and materialism ${ }^{74}$ he willingly succumbed to the Lucretian "temptation" to declare Nature capable of doing "all things spontaneously of herself without the meddling of the gods". Tyndall certainly knew that this was intellectual iconoclasm in Calvinist Belfast. But he was no less sure that it was political dynamite in Catholic Ireland too for he looked forward to the day

\footnotetext{
73 W.G., "The Darwinian Theory", p. 239.

${ }^{74}$ On the distinctive character of Tyndall's 'materialism', see Ruth Barton, “John Tyndall, Pantheist. A Rereading of the Belfast Address”, Osiris, 2nd series, 3, (1987): 111-134; S. Kim, John Tyndall's Transcendental Materialism and the Conflict between Science and Religion in Victorian England (Lewiston: Mellen University Press, 1996).
} 
when science would break "in upon the minds of the youth of Ireland" and deliver to them a sure "check to any intellectual and spiritual tyranny". "We fought and won our battle even in the Middle Ages" he announced; "why should we doubt the issue of a conflict now?" 75 All of this was part of a concerted campaign on the part of a number of professionalising scientists to wrest cultural authority from the hands of the clergy. ${ }^{76}$ And it had certainly had the desired effect, for it threw local churchmen into a spasm as Tyndall found himself at the centre of a storm of controversy, much to his delight, that winter. ${ }^{77}$ Even George Bernard Shaw put into the mouth of one of his characters, Mrs Whitefield, the comment: "Nothing has been right since that speech that Professor Tyndall made at Belfast". ${ }^{78}$

Tyndall's name, of course, was already well known to readers of the magazine. Apart from anything else, the Monthly had carried a biographical sketch of Tyndall the previous year, likely authored by Roderick Noble, in which he lauded the physicist's determined search for scientific truth. More particularly his "absolute unbelief in the facts alleged by spiritualists" received Noble's hearty approval. ${ }^{79}$ But there were clouds on the horizon too. Not least of these was Tyndall's role in the prayer-gauge controversy, which sought to test the efficacy of prayer by scientific methods; here, along with figures like Francis Galton, he had sought, as Theodore Porter nicely puts it, "to crush mystical piety under a heap of miscellaneous statistical facts". ${ }^{80}$ That introduced a coolness into Noble's otherwise enthusiastic assessment; for it demonstrated a "twist" in Tyndall's mind-set that made "a few of his writings rather dangerous for unstable minds". ${ }^{81}$

If that introduction set the tone for Tyndall's intellectual reputation at the Cape, the opening remarks that staged the reprint of his original Belfast address added a temperamental element to his public persona. Here readers were told that "notwithstanding the studied attempt at moderation of expression", the piece manifested

\footnotetext{
75 "Professor Tyndall's Address", Cape Monthly Magazine 9 (November 1874): 304-319, on pp. 318, 316, 318.

${ }^{76}$ This whole topic is the subject of Frank Miller Turner, "The Victorian Conflict between Science and Religion: A Professional Dimension”, Isis, 69 (1978): 356-376.

77 This episode is discussed in David N. Livingstone, "Darwin in Belfast: the Evolution Debate", in John W. Foster (ed.), Nature in Ireland: A Scientific and Cultural History (Dublin: Lilliput Press, 1997), 387-408. See also Bernard Lightman, "Scientists as Materialists in the Periodical Press: Tyndall's Belfast Address", in Geoffrey Cantor and Sally Shuttleworth (eds), Science Serialized: Representation of the Sciences in Nineteenth Century Periodicals (Boston: M.I.T. Press, 2004), pp. 199-237.

${ }^{78}$ George Bernard Shaw, Man and Superman (Westminster: Archibald Constable, 1903 ), Act IV, p. 164. 79 "Professor Tyndall", Cape Monthly Magazine, 6 (April 1873) 204-207, on p. 207.

${ }^{80}$ See Theodore M. Porter, The Rise of Statistical Thinking 1820-1900 (Princeton: Princeton University Press, 1986). The whole episode is discussed in Robert Bruce Mullin, "Science, Miracles, and the Prayer-Gauge Debate", in David C. Lindberg and Ronald L. Numbers (eds), When Science and Christianity Meet (Chicago: University of Chicago Press, 2003), pp. 203-224.

81 "Professor Tyndall", p. 207.
} 
"an intense bitterness of feeling" which was nothing short of astonishing. Besides, Tyndall's rhetoric was not always to be believed. The Monthly's editor wasn't convinced by Tyndall's insistence that the new version of the lecture, which had just appeared, was only slightly modified; he found it to be a very different beast indeed. A "most ominous passage" in the first printing, for example, was now "translated into harmless necessitarianism". All in all, the new printing was "so metamorphosed that had it been delivered at Belfast in its present shape it would probably have excited no other feeling than one of almost unqualified admiration for the exhaustiveness of its research and the exquisite beauty of its style". ${ }^{82}$ But the Cape Monthly readers could judge for themselves. The lengthy passage now before them was taken from the original publication in the pages of Nature. ${ }^{83}$

That was certainly the version that James Cameron, Professor of Classics and English at the South African College, and sometime Congregationalist clergyman, had read as he prepared for an evening address that October at Sea Point where, for nearly forty years, he conducted non-denominational services. ${ }^{84}$ The November issue of the Monthly carried the full text of his homily. Cameron had earlier expressed his views on the need to separate science and religion into different provinces in a lecture to the South African Public Library in 1870 as a means of dealing with the threat of materialism in physical science. In surveying the current intellectual scene, he had paused to comment on those "who rejoice in the present growth of Physical Science, because they believe that it will deliver the world from the bondage of religious creeds and doctrines which they have learnt to dislike. They believe that Science is to displace Theology from its long sway over the life of man," he lamented, "and substitute the certainties of ascertained fact for the fluctuations of faith" ${ }^{85}$ Now, in 1874 , he was thus particularly peeved to see the way Tyndall had violated established protocol by using his position as President of the British Association to speak on subjects far beyond his remit - something that local opponents in Belfast also fastened upon. ${ }^{86}$ Tyndall simply had not confined himself "as his predecessors in the chair had done, to a calm and critical survey of the progress of science"; instead he had chosen to transgress the boundary between science and faith by

\footnotetext{
82 "Professor Tyndall's Address", pp. 305, 306, 305.

83 John Tyndall, "Inaugural Address", Nature 10 (August 1874): 309-319.

${ }^{84}$ Dictionary of South African Biography, Vol. II, 119-120.

${ }^{85}$ Rev. Professor [James] Cameron, "Address", Proceedings at the Forty-First Anniversary Meeting of the Subscribers to the Public Library, Cape Town, Cape of Good Hope, Held on Saturday, the 21 ${ }^{\text {st }}$ May, 1870 (Cape Town: Saul Solomon, 1870), pp. 7-29, on p. 24.

${ }^{86}$ See the discussion in David N. Livingstone, "Science, Site and Speech: Scientific Knowledge and the Spaces of Rhetoric", History of the Human Sciences 20 (2007): 71-98.
} 
using "his high position for the purpose of advocating and developing those views which have already done so much to shock the religious sense of his countrymen". By so doing he "took his place with those who reject Christianity as a delusion, and a living God as a fast-dying superstition". Along the way Cameron also insisted that it was folly to cleave to the idea of religious sentiment as serviceable to the human race while querying the objective reality of God's existence, hit out at reductionist atomism, and turned Tyndall's sour comment on Newton's theological predilections back on himself: "the comfort and assurance which Christians may have from the fact that Newton wrote in defence of Christianity are at least as reasonable as any fear and trembling which may arise from the fact that Professor Tyndall denounces it as a superstition". ${ }^{87}$

The next month's issue of the magazine carried another Belfast intervention, this time by the Unitarian clergyman Rev John Scott Porter who served as Professor of Sacred Criticism and Theology to the Association of Non-Subscribing Presbyterians in Ireland and was the author of somewhere around 40 works. ${ }^{88} \mathrm{An}$ ardent anti-Trinitarian who opposed radical ideas and Calvinist orthodoxy alike, Porter had been present at Tyndall's address and had published a rejoinder a week or so after the event ${ }^{89}$ which the Cape Monthly now saw fit to reprint. How the paper came within the purview of the magazine is not difficult to infer, given that Porter's brother William, to whom we will presently turn, had served as Attorney-General for the Cape Colony and was himself present at the British Association meeting in Belfast. Indeed the editor told readers that in the article before them he fancied he could hear the "ringing eloquence" and feel "the generous humour and rich philosophy even of William Porter himself". ${ }^{90}$

Scott Porter's aim was to counter Tyndall's account of atomism and the species of atheism with which he seemed to associate it. And while its tone was less savage than the mainstream Presbyterians who rounded on Tyndall in response to the "open and

\footnotetext{
${ }^{87}$ Rev. Dr. Cameron, “On Professor Tyndall’s Address”, Cape Monthly Magazine 9 (November 1874): 256266, on pp. 258, 261.

${ }^{88}$ Such as John Scott Porter, Twelve Lectures in Illustration and Defence of Christian Unitarianism : Delivered in the Meeting-House of the First Presbyterian Congregation (London: Green, 1841); idem, Principles of Textual Criticism: With their Application to the Old and New Testaments Illustrated with Places and Facsimiles of Biblical Documents (London: Simms and M'Intyre, 1848); idem, Lectures on the Doctrine of Atonement (London: Whitfield, 1860). Biographical details are available in Dictionary of Irish Biography Vol. 8 (Cambridge: Cambridge University Press, 2009), pp. 234-236.

89 J. Scott Porter, The Existence and Attributes of the Invisible God Made Manifest through his Visible Works: A Discourse Delivered on the $30^{\text {th }}$ August, 1874 in the First Presbyterian Church, Rosemary Street, Belfast; In Which Some Statements Made by Professor Tyndall in his Inaugural Address, Read at the Annual Meeting of the British Association for the Advancement of Science, are Briefly Considered (Belfast: Wm. Henry Greer, 1874).

90 “The Rev. John Scott Porter on Professor Tyndall", Cape Monthly Magazine 9 (December, 1874): 376-384, on p. 376.
} 
determined onslaught" to which they believed they had been subjected, ${ }^{91}$ its scepticism over Tyndall's use of the atomic theory to justify a purposeless universe was plain for all to see. From the outset Porter's liberalism expressed itself in his rigorous defence of Tyndall's right to express his views on any subject and, in marked contrast to others, he deliberately chose not to censure him for "the place and the occasion which he chose for ventilating his theories". The "largest toleration for every species and degree of what is regarded as error", he declared, had to be jealously guarded. But the right to contest opinions was no less a moral duty. His own grievance centred on the proposal that mere matter contained within it, to use Tyndall's own words, "the promise and potency of every form and quality of life". Without a guiding intelligence behind it, that just seemed entirely wrong-headed to Porter. But more. Porter was sure such inflated claims lacked any factual corroboration and thus strayed far beyond the realm of empirical science. It was all "mere hypothesis", a tissue of groundless speculation. This did not mean, of course, that atomism was of itself irreligious. It was patently false to presume that those who adopted "the chemical theory of atoms, or the nebular theory of astronomy ... are necessarily to be classed among the deniers of an All-wise Creator", Porter continued as the names of figures like Robert Boyle, Isaac Newton, Joseph Dalton, and John Pringle Nichol amply attested. ${ }^{92}$ To wed atomism to sceptical materialism was a contingent, not a necessary association.

In August, 1876, the Monthly printed yet another communiqué originating in Belfast the inaugural address of Hon. William Porter, Scott's brother, on his installation as First Chancellor of the Cape University which had been instituted in 1873. Now retired to Ireland, William presented his reflections on current intellectual developments and paused to comment on evolution and its most prominent advocates. The liberal, though at times apprehensive, tone that characterised many of the interventions in the immediate aftermath of Dale's Library address and Tyndall's Belfast lecture, also typified his commentary. William, born in Ulster 1805, into a liberal New Light Presbyterian manse, had been appointed in 1839 as Attorney-General of Cape Colony. ${ }^{93}$ With strong liberal convictions, deriving in part from his Unitarian principles, he worked tirelessly for equal justice for black and white, masters and servants, alike, and the constitution he drew up in 1854 provided for a parliament elected by all races on equal terms. For all his

\footnotetext{
${ }^{91}$ This observation was reported in "The Belfast Presbytery and the British Association", The Witness, 4 September 1874.

92 “The Rev. John Scott Porter on Professor Tyndall”, pp. 376, 378, 380, 381

${ }_{93}$ Biographical details are available in J. L. McCracken, New Light at the Cape of Good Hope: William Porter, the Father of Cape Liberalism (Belfast: Ulster Historical Foundation, 1993). See also Dictionary of South African Biography, Vol. I, pp. 623-626.
} 
humanitarianism, however, he later reneged on his support for Xhosa famine relief judging that "idleness" was the Xhosa's "besetting sin" and turning against what he believed to be Khoikhoi treachery in asserting their land ownership. ${ }^{94}$ At the same time he strenuously campaigned for religious freedom, the provision of higher education for men and women alike, and the abolition of capital punishment in the Cape. ${ }^{95}$ In his early years he acted, for a period, as secretary of the Irish Unitarian Christian Society contributing several articles to a journal edited by his brother Scott in which he claimed that evangelicalism, with what he took to be its contempt for literature and science, had an inherently corrupting inclination. Given these sentiments it is not at all surprising that he enthusiastically supported the activities of the South African Library which, as Dubow observes, he saw as "a beacon of enlightenment and education", ${ }^{96}$ describing it as "the Library of every man in the community" and fundamental to "the instruction of the people - of the whole people - of the people of every age, and sex, and class, and colour". ${ }^{97}$ In 1873 he returned to Ireland where he lived with his brother in Belfast until his death in 1880. During these years he witnessed first hand the altercations over Darwinism that were stirred up in the city by Tyndall's presidential pronunciamento.

William made it clear that many students of Darwinism did not think it either pernicious or destructive, and confessed that on the subject he "dare not dogmatise". But he remained cautious. It was disturbing that "Atheism, - avowed, aggressive, and here and there almost intolerant - is preached as the first and legitimate outcome of Physical Science". And so he expressed considerable disquiet over the radically naturalistic Darwinism of Haeckel - concerns that mirrored the fears about the Tyndallinspired scientific 'atheism' that John had expressed a couple of years earlier and which the Monthly had reprinted at the time. To William Porter, mechanistic accounts of the human species that denied teleological operations were deeply troublesome. For in teaching that what was long thought to be designed was nothing but the product of "the blind mechanical actions of the atoms, the only eternal things", they presented a picture of Nature as nothing "admirable" but "full of blunders". That was bad enough. But there was more. Porter was certain he could detect “indications ... in Professor Haeckel's book that his scientific creed has tended to pervert, at least in theory, his moral

\footnotetext{
${ }^{94}$ See Lester, Imperial Networks, pp. 183, 158.

${ }^{95}$ Finlay Holmes, "Porter, John Scott (1801-1880)", Oxford Dictionary of National Biography, Oxford University Press, 2004; online edn, Jan 2008 [http://www.oxforddnb.com/view/article/22573, accessed 17 Nov 2015].

${ }^{96}$ Dubow, Commonwealth of Knowledge, p. 48.

${ }^{97}$ Proceedings at the $11^{\text {th }}$ Anniversary Meeting of the Subscribers to the Public Library, Cape Town, Tuesday, $28^{\text {th }}$ April, 1840 (Cape Town: Saul Solomon, 1840), pp. 4-5, 6.
} 
sentiments". What disturbed him most was the heartless eugenic rhetoric that was often on Haeckel's lips. Killing off “all sickly, weak, and crippled children” as an act of "artificial selection, to promote the survival of the fittest", and the way in which Haeckel derided "the cry which the 'so-called human Civilization' would set up against any one who should now make such a proposal” did not exactly warm Porter's heart. "Christendom", he proclaimed "does not kill its sickly, weak, and crippled children. It builds hospitals for them". How different that creed was from Haeckel's Darwinian vision of a world characterised by "a pitiless and most embittered struggle of all against all". ${ }^{98}$ All of this, Porter was convinced, was rooted in materialist and mechanical conceptions of human understanding that subverted human dignity.

Porter's worries about these forms of radical Darwinism need to be placed in the context of the New Light Presbyterian - Unitarian - liberalism he shared with his brother. For his address was dominated by a pervading sense of the role of education in cultivating social cohesion, civic ethics, moral improvement, material prosperity, and mental resources. Anything that would sabotage these Enlightenment virtues by substituting materialist values for moral sentiment was politically - and religiously intolerable. And that was precisely what Haeckel-style Darwinism threatened to do - to undermine the high moral and anti-materialist ethos of South Africa in general, and the new University of Cape Town in particular. For someone powerfully animated by New Light liberalism on race relations, a hatred of oppression, and faith in progress, the face of dark Darwinism that Haeckel represented was nothing short of sinister.

Porter's discourse was soon the locus of some debate. Writing under the pseudonym 'Omega', a member of the new university charged him with "conservative prejudices", with a determination to "repress" research in "all branches of Biology", and with an inclination to squeeze Darwin into "harmony with an a priori conception of his own". These accusations were the subject of a rebuttal in the December volume of the magazine. The anonymous author insisted that it was Haeckel, rather than Darwin, who was the object of Porter's scorn and that in all likelihood Haeckel would concede that Porter had interpreted him aright. As for the Darwinian component, the author insisted that the only point at which this charge seemed remotely relevant was when Porter described Haeckel's views as "Darwinism developed". Whether or not that was an appropriate designation, it was simply wrong to infer that Porter was accusing Darwin of

98 William Porter, “On Scholastic and Philosophic Studies”, Cape Monthly Magazine 13 (August 1876): 6581 , on pp. $76,77,78$. 
Haeckel's "extravagance". Indeed the writer felt sure that "Mr. Darwin would endorse the statement". 99

Intellectual trafficking between Belfast and Cape Colony did much to shape how Darwin's theory was talked about among the English-speaking cognoscenti in the wake of Tyndall's bolt from the blue. And, to some degree at least, it continued to cast its shadow over the Monthly's rendezvous with Darwin in the months and years that followed.

\section{The Spectre of Materialism}

In the aftermath of Tyndall's onslaught, matters of materialism, atomism, and teleology were now firmly lodged at the heart of debates at the Cape over the new evolutionary science of life. And they continued to be taken up by the Monthly's correspondents. Writing under the initials S.C.N., for example, one writer contributed a range of articles over the following months on related themes. Materialism was the first port of call. "Great has been horror expressed against this fearful bugbear" the author began. But more careful scrutiny would soon show that "we are somewhat too apt to disquiet ourselves in vain" for the "supposed materialist will often be found to be as much a mystic as anything else". A set of philosophical reflections on the properties of matter led S.C.N. quickly to the conclusion that a properly construed "metaphysical conception of the material universe ... is equally in harmony with the old and new theories of creation and evolution". ${ }^{100}$

S.C.N.'s own firm commitment to Darwinism clearly manifested itself in a response he penned to a squib that appeared in the May 1875 issue by another depersonalised author, this time A.E.M., under the title "A Voice from the Unlearned on Scientific Discoveries". Having just weathered the storm waves blown up by John William Colenso, the Anglican Bishop of Natal who questioned the historical accuracy of certain biblical passages, A.E.M. now pinpointed Darwin and Tyndall as the next challenges on the horizon. In Darwin's case there certainly was "something to startle". Speaking up for the unlearned he wondered how Darwin or anybody else could determine whether "the monkey developed out of the crab, or the crab out of the monkey" - or bees out of either. The birth of no new species had ever been witnessed, he urged, and in the place of conclusive evidence the Darwinians traded much too liberally in the "conjectural and

\footnotetext{
99 “'Omega's' Criticism of Mr. Porter's Address to the Cape University”, Cape Monthly Magazine 13 (December 1876): 377-381, on pp. 378. 379, 380.

100 S.C.N., "On Materialism”, Cape Monthly Magazine 10 (February 1875): 112-116, on pp. 112, 116
} 
hypothetical". "We think highly of you, Dr. Darwin" A.E.M. observed; “you are a hardworking, careful, honest, clever man. Go on try again! You have nearly found out something, and you have possibly done some good: at all events you have done us no harm; but at present our verdict regarding the development theory must be 'not proven"”, ${ }^{101}$ The same judgment, however, could not be passed down on Tyndall. There was nothing to startle here, only a warmed-over old theory - atomism. What was strange, though, was that such a view could attract such an eminent advocate.

S.C.N. quickly responded and began nit-picking even while acknowledging that "the tone" in which A.E.M. had "apostrophised" Darwin was "so good humoured and tolerant that the article is a pleasing one for even an evolutionist to read". To S.C.N. the "stock arguments" about crabs, bees and monkeys, never mind missing links, hybrid sterility, the disappearance of species, and such like, were "founded on glaring misconceptions" of nature's operations and the mechanisms that horticulturalists and pigeon-fanciers used to produce stable varieties. As for "the allegation" that evolution was "impious and profane", S.C.N. quoted Thomas François Burgers, fourth President of the South African Republic, to the effect that it was highly doubtful that "it redounded more to the glory of God that we should imagine that He brought the universe into being by a few spasmodic creative acts" than that "He gradually and harmoniously evolved it by marvellously subtle and beautiful processes". To S.C.N. the thought that evolution was "necessarily irreverent" was "an accusation that scarcely requires to be seriously combated". ${ }^{102}$

Lest too much comfort might be taken from that closing prescription, however, S.C.N. drew the piece to a conclusion by anonymously quoting Thomas Henry Huxley's quip that "Extinguished theologians lie about the cradle of every science as strangled snakes beside that of Hercules; and history records that whenever science and orthodoxy have been fairly opposed, the latter has been forced to retire from the lists, bleeding and crushed, if not annihilated". ${ }^{103}$ That sentiment was certainly in keeping with S.C.N.'s outlook for, in the meantime, another article entitled "On Human Barbarity" had appeared under the same initials. Here the history of human culture was cast as a story of evolving ethical advancement from a benighted past to an increasing enlightened present. In this panoramic conspectus, the Church fared pretty badly. For S.C.N. adduced case after case of churchmen glorying in the torture of witches. And it was

101 A.E.M., “A Voice from the Unlearned on Scientific Discoveries”, Cape Monthly Magazine 10 (May 1875): 263-268, on pp. 263, 265, 266.

102 S.C.N., "The Crab, Monkey and Bee Theory", Cape Monthly Magazine 11 (July 1875): 15-17.

103 S.C.N., "The Crab”, p. 17. 
notable, the author reckoned, that as soon as "orthodoxy began to grow alarmed at the revival of learning ... a more severe view was taken of these supposed dealings with Satan". Whether it was "Presbyterian Scotland", "Protestant Holland" or "Christian Europe" more generally the self-same impulse towards "blood-shedding" manifested itself all too commonly. ${ }^{104}$

By contrast to S.C.N.'s diagnosis, a sense of impending gloom about Darwinianinspired materialism pervaded the assessment provided by the Scottish Presbyterian minister James Turnbull. Currently at Greytown in Natal, having ministered in Cape Colony for eight years or so, ${ }^{105}$ Turnbull provided his assessment of Darwinism as a cosmological theory in a piece stretching over the 1875 September and October issues of the Monthly. Darwin's theory, he began, found a natural ally in Democritus-style atomism though he insisted that it was "a form of human thought and belief well worthy of the student of the higher branches of the knowable". What caught his attention, though, were not the empirical particulars with which it was associated - natural selection, species transformation, human evolution or the like. Rather it was the cosmic credo that Darwin's theory had nurtured. The Darwinian universe presupposed a Creator, to be sure, but to Turnbull, one "entirely different from the God revealed in scripture". ${ }^{106}$ The Origin of Species might well have projected the creation of the first atom, but thereafter Darwin's deist divine exempted himself from the universe. And the consequences of that retreat were manifold. Darwinian cosmology replaced Providence with mere accidental variation as the driving force of organic change and thus banished final causes from nature's realm. It merged the soul "into the abyss of the unknown infinite of a material pantheism", not least in the case of the critical German theologian David Friedrich Strauss who found something in Darwinism to "console him to his own soulless conclusions". Moral reductionism was another outcome. For Darwinism had the effect of extracting the teeth of moral judgment by surrendering humanity to those appetites and passions which, inherited from a bestial past, were either "sublimated or elevated by natural selection". ${ }^{107}$ Because such obscenities as "cannibalism, murder and fratricide" were simply hereditary impulses, Turnbull observed, "we must not look upon such acts as being positively sinful, deserving of punishment". Not of course, that Darwin advocated any or all of these developments. "It is not always safe to throw upon a man

\footnotetext{
104 S.C.N. "On Human Barbarity”, Cape Monthly Magazine 10 (May 1875): 257-262, on pp. 259, 260.

105 Dictionary of South African Biography, Vol. III, p. 789.

106 Rev. J. Turnbull, "Darwinism: Its Value as a Cosmological Theory", Cape Monthly Magazine 11 (September 1875): 184-189; (October 1875): 212-225, on p. 187

107 Turnbull, “Darwinism”, pp. 223, 224.
} 
the consequences of his creed" Turnbull conceded. Nevertheless he was convinced that "the teaching of Darwin must be placed in the school of Huxley, Tindall [sic], Mill, Strauss" and the like. ${ }^{108}$

For his part, Langham Dale, now writing under the insignia $\Delta$ (Delta), continued to express concerns over the way in which "the teachings of positive and materialistic philosophers have permeated the minds of thinking men". ${ }^{109}$ In an 1879 review of "Modern Philosophy" he reported that anti-miraculous and anti-teleological views of history and nature were gaining ground as "mechanico-causal" explanations gripped scientific imaginations. Dale had Tyndall, Haeckel, Helmholtz, Huxley and the like in his sights as he reported on the ways in which "scientific materialism" would "cut away the whole basis of Revelation, Tradition, and Mythology" alike. To be sure, there were elements in popular Christianity - "the heaven of oriental imagery, and the Echenna of the Hebrew, as also the Hell of Dante and Milton" - which were happily making their exit from theological confession. ${ }^{110}$ But he was pleased to report on the reaffirmation of design in the universe by the likes of Lord Kelvin and Clerk Maxwell. For all that, Dale wanted to preserve scientific freedom and the neutrality of genuine physical inquiry, and so he paused to challenge as "absurd" the stance of the Victoria Institute which had been found in Britain in 1865 to defend the "great truths revealed in Holy Scripture ... against the opposition of Science falsely so called". ${ }^{111}$ Its raison d'être, as Dale saw it, was to investigate scientific questions "with the view of reconciling any apparent discrepancies between Christianity and Science". ${ }^{112}$ To Dale, however, that was all wrong. For it presupposed precisely what should be the subject of objective scrutiny. A "fixedprejudgment" was entirely incompatible with proper investigation. In this way, Dale could at once express his own disquiet at the direction in which science was moving, even while defending "the most unrestrained freedom of thought and research". ${ }^{113}$ The theory of evolution had surely shaken aspects of the old faith, yet Dale could happily conclude that it had neither undermined "cause and design in nature" nor destroyed "the essence of Christianity, apart from its aftergrowth of theological dogmas, anthropomorphisms, and ceremonial observances". ${ }^{114}$ And this was of vital importance,

108 Turnbull, "Darwinism”, pp. 224, 222

${ }^{109} \Delta$, "Modern Philosophy", Cape Monthly Magazine 19 (September, 1879): 184-188, on p. 184.

${ }^{110} \Delta$, "Modern Philosophy", p. 185.

111 "Object of the Victoria Institute", Journal of the Transactions of the Victoria Institute 1 (1857): vi. See the discussion in Ronald L. Numbers, The Creationists: The Evolution of Scientific Creationism (New York: Knopf, 1992): pp. 140-144.

$112 \Delta$, "Modern Philosophy", p. 186.

$113 \Delta$, "Modern Philosophy", p. 187.

${ }^{114} \Delta$, “Modern Philosophy”, p. 188. 
not least in a place like Cape Colony. For the "consolations of Christianity" were the "only mental and moral food" that could sustain "the majority of those whose lives are spent from dawn to dark in winning bread for their households" and the only way to cultivate in many a "dutiful obedience to their Creator". Should that moral universe collapse under the weight of evolutionary materialism the consequences would be disastrous, especially if religious leaders made public profession of their own revisions to traditional dogma. For that would "disturb the happy child-like faith of others who are going steadily and happily on their way, rejoicing in simple endeavours to do their duty in the state in which they believe God to have placed them". Drawing inspiration from the unorthodox and controversial James Anthony Froude who had recently advocated the use of forced labour on the Xhosa people - though he only identified him in the piece as the author of Short Studies on Great Subjects - Dale commended to his readers the view that religion's true worth lay in its cultivation of charity, self-sacrifice, and "those graces which raise human creatures above themselves". ${ }^{115}$

\section{Darwinian Imaginations}

Fears about the metaphysics of evolutionary materialism, of course, was not a universal preoccupation. Others simply assumed the truth of Darwinian evolution and put it to work for their own purposes. An anonymous writer on the "Origin and Antiquity of Man”, for example, just presupposed that human evolution had occurred and called on Mivart's dualism to alleviate any theological tensions. Reviewing the emerging evidence for early human development - the discovery of flint implements, cave art, lake dwellings, kitchen middens and the like - the author insisted that "Not only is the belief in man's vast and still unknown antiquity universal among men of science, but it is hardly disputed by any well-informed theologian". Indeed to this correspondent "the present generation of science-students must ... be somewhat puzzled to understand what there was in the earliest discoveries that should have aroused such general opposition and been met with such universal incredulity". After all Mivart had shown how perfectly coherent it was to adopt evolution "as regards physical structure" while seeking an alternative account of "man's whole intellectual and moral nature". ${ }^{116}$ The writer's concern, however, was with the tendency of some evolutionists to over-exaggerate the very great antiquity of the human race to comply with their theoretical prescriptions - and in advance of empirical corroboration. Evidence that the brain size of the Cro-Magnons,

${ }^{115} \Delta$, "Modern Philosophy", pp. 185, 186.

116 "Origin and Antiquity of Man”, Cape Monthly Magazine 13 (November 1876): 310-314, on p. 311. 
for example, was no different from modern humans was one cautionary piece of evidence. And the existence of early works of art in cave-dwellings "executed with considerable skill on bone" was another indication of "a considerable degree of mental advancement" in these early humans. Such claims gave support to Daniel Wilson's degenerationist thesis that "it is easier to produce evidence of deterioration than of progress in instituting a comparison between the contemporaries of the mammoth and later prehistoric races of Europe or savage nations of modern times". ${ }^{117}$ And they impressed on the writer the thought, bolstered by Alfred Russel Wallace's recent comments at the British Association, that Homo Sapiens might well be of more recent origin than many ardent Darwinians assumed.

Others, meanwhile, had been mobilising evolutionary narratives for quite different purposes. In a three-part series introducing readers to the geology of South Africa, the English-born geologist, ethnologist, poet and watercolourist, George W. Stow sketched something of the different epochs through which the earth had passed. ${ }^{118}$ The articles showed Stow to be fully abreast of current developments in the earth sciences but that did nothing to weaken the doxological science to which he was committed. Instead, the profound sense of deep time that pervaded his narrative impressed on him a marked sense of awe and wonder. When pondering on the increase of insect life since the end of the Palaeozoic Era, he exclaimed: "Surely the result of such studies as these must be to fill us with astonishment and deep feelings unknown before, if we but for a moment meditate how these things reveal to us, through ages whose numbers we cannot conceive, the eternal wisdom and perfection of the works of the great Creator". ${ }^{119}$ And that was entirely in keeping with the sense of evolutionary teleology that manifested itself in his account of human development. No sooner had he paraphrased Huxley's observation that "the anatomical divergences between the highest anthropoid ape and the lowest type of man is much less than that between the lowest man and the highest Caucasian" than he added: "Thus with regard to the history of life on the earth, science seems to teach us that in the divine mind there was no need of after thoughts - no need of experimental or successive creations, - but that there was one grand stream of vitality,

\footnotetext{
117 “Origin and Antiquity of Man", p. 313. The author was reporting on Wallace's presidential address to the Biology Section of the British Association. See Alfred Russel Wallace, "Rise and Progress of Modern Views as to the Antiquity and Origin of Man", Report of the British Association for the Advancement of Science 46 (1876): 100-119.

118 Geo. W. Stow, “On the Study of Geology, Part 1" Cape Monthly Magazine 10 (February 1875): 95-100; "On the Study of Geology, Part 2" Cape Monthly Magazine 10 (March 1875): 160-173; "On the Study of Geology, Part 3" Cape Monthly Magazine 10 (May 1875): 273-284.

119 Stow, "On the Study of Geology", p. 164.
} 
that issuing from the beginning from that glorious First Cause, has continued its onward progress from then until it has reached ourselves!"120

Geological history, however, was not the only sphere in which Stow found evolutionary thought-forms fertile. Shortly after completing a geological survey commissioned by the Orange Free State and reporting in 1878-79 his discovery of extensive coal seams at Makouvlei on the banks of the Vaal River, he began putting together the ethnological notes from his extensive travels for his monumental The Native Races of South Africa. He finished the task in 1880 but for some reason the manuscript was not finally published until 1905, some twenty-three years after his death. Here evolutionary vocabulary strongly featured. But in this case - in applying the idea of the struggle for existence to the Bushmen of South Africa - a far darker ethno-cosmos surfaced. ${ }^{121}$ Painstakingly cataloguing the atrocities to which they had been subject, what he called the "remorseless butchery and indiscriminate slaughter of the unhappy Bushmen", Stow sketched a truly "terrible drama" in which "a civilized government sanctioned the policy of extermination". ${ }^{122}$ And so while the idea of struggle provided him with the Leitmotif of his ethnic history, the triumphalist apologetics often associated with racialised Darwinism was conspicuous only by its absence.

It was very different for George McCall Theal, Stow's later editor, who had taken on the task of putting the notes in order for publication. Indeed, according to Dubow, Theal sought to give The Native Races "a distinctly pro-settler slant, which is largely absent in Stow's work" and his own later volume on The Yellow and Dark-Skinned People of Africa South of the Zambesi showed him to be "a proto-colonial nationalist deeply imbued with the ideas of Social Darwinism". ${ }^{123}$ In his case Darwinian vocabulary was harnessed in support of his conviction that the triumph of white settlement was the natural outcome of the survival of the fittest. Stow's account, by contrast, was suffused with a kind of nostalgic admiration for the Bushmen's "love of country" and the patriotism they displayed in their "dire but hopeless struggle for life", as well as by a pervading sense of regret that they were "looked upon by all the larger and more robust of the African races as a species of wild animal which it was praiseworthy to exterminate". ${ }^{124}$ Indeed judging

\footnotetext{
120 Stow, "On the Study of Geology", pp. 282-283.

121 George W. Stow, The Native Races of South Africa: A History of the Intrusion of the Hottentots and Bantu into the Hunting Grounds of the Bushmen, the Aborigines of the Country, edited by George McCall Theal (London: Swan Sonnenschein, 1905). Chapter 12 is entitled "The Struggle of the Bushmen for Existence". 122 Stow, The Native Races, pp. 215, 214.

123 Saul Dubow, Scientific Racism in Modern South Africa (Cambridge: Cambridge University Press, 1995), pp. 68-69; George McCall Theal The Yellow and Dark-Skinned People of Africa South of the Zambesi (London: S. Sonnenschein, 1910).

124 Stow, The Native Races, pp. 230, 218, 215.
} 
from the rock art that survived, Stow was certain he could detect in the ancient Bushmen "the first rippling wave of that advancing tide of civilization which was thrown off from the grand centre of its birth". ${ }^{125}$ For both Stow and Theal evolutionary theory assumed a critical role in the cultural politics of race relations in South Africa; at the same time their different uses of Darwin revealed something of just how versatile his theory was in servicing racial ideologies of varying hues. And William Bisset Berry's resort to it to unearth resources for addressing a current legal conundrum in the Cape further illustrates the point.

The issue here rotated around the tensions involved in applying general legislative principles in a society where long-established local customs fell foul of imperial proclamations. Was it "unmerciful and unjust to have one set of laws and institutions" for both "Shemite and Hamite entities", or should there be "one public law" for all? 126 Should the law be colour-blind or not? That was the question - how to balance universal justice with cultural relativism, and nowhere was this friction so pointedly manifest as in the practice of tribal polygamy. Berry was convinced that evolutionary theory provided a way out of the impasse. Because of the central role of adaptation in the Darwinian scenario, it seemed to Berry that to "subject any organism to a great and sudden change must be a source of great evil to such a organism" for the simple reason that its features had been preserved by virtue of their significant survival value. ${ }^{127}$ To be sure, Darwin primarily had in mind the evolution of the physical constitution in elaborating his law of natural selection. But Berry was sure there was an "analogous law" which applied to the "mental constitution" and that meant that "revolutionizing" a "social system" by the rough-shod application of imperial legislation was seriously ill-advised. Hastening slowly - "festina lente" - Berry insisted "should be our motto". To Berry, then, the cultivation of a single legislative system was the right way to proceed but it was no less fitting to temper its obligations to "native subject-allies", by what he called "a salutary laissez-faire", until, in true evolutionary fashion, they gradually adapted their culture to its requirements. ${ }^{128}$ While in some places Darwinian language could be called upon to underwrite colonial extermination and tribal dispossession, here it was enlisted to rationalize cultural amalgamation and gradualist assimilation.

\footnotetext{
125 Stow, The Native Races, p. 233. Stow's art work is the subject of Pippa Skotnes, Unconquerable Spirit: George Stow's History Paintings of the San (Athens, OH: Ohio University Press, 2009).

${ }^{126}$ W. Bisset Berry, "Evolution and Class Legislation”, Cape Monthly Magazine 11 (June 1875): 321-327, on p. 321.

127 Berry, "Evolution and Class Legislation", p. 322.

128 Berry, "Evolution and Class Legislation", pp. 322, 323, 324.
} 
Taken in the round, the Darwinian conversations among supporters of the South African Library and The Cape Monthly Magazine during the late 1860s and 1870s were imbued with liberal sentiments. Within the space of the English-speaking intellectual elite, support for the theory was judicious, criticism cautious. The largely temperate tone that interlocutors adopted was entirely in keeping with the progressive, Enlightenment aspirations of the Cape's literati whose eyes were firmly fixed on science's metropolitan horizon. While frequently judged at the bar of theology or metaphysics, from time to time Darwin's theory was called upon to do scientific work. And when such research approached questions of race - as they most clearly did in evolutionary accounts of language - they caused little disquiet, doubtless because they confirmed a monogenetic account of human unity and, at the same time, could readily be seen as reinforcing the paternalistic ideology that governed colonial affairs. The implications of Darwin's theory for local politics were not prominently paraded, however; but they were certainly not far beneath the surface, for when Darwin's champions pushed the theory in materialist or sceptical directions that threatened to destabilise the civic, moral or pedagogic progressivism that was at the heart of their liberalising institutions and civilising credo, urbane censure was certainly forthcoming.

Interrogating the debates over Darwin's theory of evolution at the Cape during the nineteenth-century fin-de-siècle opens up dialogue with a range of ongoing concerns to students of historical geography. As a case study in the circulation of scientific knowledge, the story of Darwin's fate at the Cape demonstrates the continuing need to resist the inclination to trade in philosophical generality by abstracting the impact of science from the particularities of period and place; instead it invites us to further pursue the project of uncovering the diverse historical geographies of science by probing local encounters with new ideas and tracing how they were mobilised for interests of very different kinds. ${ }^{129}$ At the same time, it troubles any easy assumption that the ideology of science in colonial settings can readily be generalised: the resort to Darwinian vocabulary,

\footnotetext{
${ }^{129}$ See David N. Livingstone, "The Spaces of Knowledge: Contributions Towards a Historical Geography of Science" Society and Space, 13 (1995): 5-34; Charles W.J. Withers, "The Geography of Scientific Knowledge", in Nicolaas A. Rupke, (ed.), Göttingen and the Development of the Natural Sciences (Göttingen: Wallstein Verlag, 2002), pp. 9-18; David N. Livingstone, Putting Science in its Place: Geographies of Scientific Knowledge (Chicago: University of Chicago Press, 2003); Simon Naylor, "Historical Geography: Knowledge, In Place and On the Move", Progress in Human Geography 29 (2005): 626-34; Richard C. Powell, "Geographies of Science: Histories, Localities, Practices, Futures", Progress in Human Geography, 31 (2007): 309-329; Diarmid A. Finnegan, The Spatial Turn: Geographical Approaches in the History of Science", Journal of the History of Biology 41 (2008): 369-388; David N. Livingstone, Dealing with Darwin: Place, Politics and Rhetoric in Religious Engagements with Evolution (Baltimore: Johns Hopkins University Press, 2014).
} 
for example, to justify imperial dispossession, racial hierarchy and like - inclinations conspicuous elsewhere - obtrudes far less frequently in the Cape Montbly debates than might have been imagined. At the same time it renders troublesome any simple bifurcation between metropolitan core and colonial periphery. The production of highly distinguished scholarly work at the Cape, notably in the case of Bleek, together with the passionate concern of the Cape community to involve itself in a cosmopolitan conversation with the latest European ideas, reveals just how porous the frontier line was between home and abroad. The circulation of people and print between Britain and the Cape, together with the reprinting of texts generated far away - as in the case of Tyndall's Belfast address and responses to it - further underscores the mutual making of scientific knowledge and local encounters with it. At the same time, the particularities of conditions in the Cape meant that Darwin's theory was mobilised there for rather novel purposes, not least by Berry in seeking ways to think creatively about developing legislation applicable to settler and indigenous communities alike.

Scientific knowledge remains of the most potent forces on the face of the earth. Only by inspecting how specific communities in specific locations dealt with its latest proposals will we come to understand how its power operates over space and time. 